\title{
Explaining the Change in India's Foreign Policies Towards Russia (1947-2013): Constructing the Theory of Potential Ally's Reliability and External Threat
}

\author{
Ning $\mathrm{Li}^{1, \dagger, *}$ Xiantong $\mathrm{Lu}^{2, \dagger, *}$ Yiling Zou ${ }^{3, \dagger, *}$ \\ ${ }^{1}$ China Foreign Affair University, Beijing 100037, P.R. China \\ ${ }^{2}$ Shanghai World Foreign Language Academy, Shanghai 200233, P.R. China \\ ${ }^{3}$ Shanghai Foreign Language School Affiliated to SISU, Shanghai, 200083, P.R. China \\ *Corresponding author. Email: ${ }^{1}$ lining@mail.cfau.edu.cn, ${ }^{2} 13611691572 @ 163 . c o m,{ }^{3} 3493641598 @ q q . c o m$ \\ These authors contribute equally.
}

\begin{abstract}
The relations of medium-sized countries and hegemons are very complex. A typical example is India-Russia bilateral relationship, which has been fluctuating during the period from 1947 to 2013. This paper is aiming at exploring the determinants of India's ever-changing foreign policy to Russia. This paper uses the case study method to achieve this aim. To be more specific, through the case study of India-Russia, the research hopes to have broader lessons of exploring the relationship between medium-sized countries and hegemons. The research reveals that external threats and reliability of potential allies can explain such fluctuation. This paper will use the words reliability and credibility interchangeably. Moreover, the theoretical and practical significance of this research is as follows. Theoretical significance is two-fold: firstly, it simplifies the existing theory of level of analysis_reducing the variables. Secondly, by setting only two variables, this research successfully avoids the overlapping of variables thus procure a relevantly clear logical chain. As for practical significance, the essay is useful to provide policy recommendations to the national government about how to sensibly deal with the relationship of India and predict India's interest and policy_-India is profit-oriented, so the key is to seek the common interest. Last but not least, this paper still leaves much to explore. First, the paper is limited in the way that apart from the variables discussed in our essay, there may be other variables that might have contributed to the India-Russia relationship which are not taken into account. Additionally, the adaptability of theory is limiting. In other words, it may not fully apply to other cases. In response to this, further studies can look into other variables, such as economic ties, energy.
\end{abstract}

Keywords: reliability, internal-external threat, 1947-2013, India-Russia relationship

\section{INTRODUCTION}

Starting from 1947, the relations between India and Russia had kept changing, which attracted many scholars' attention. Therefore, this essay mainly focused on the question of why the India-Russia relationship had fluctuated since the beginning of the Cold War. There are still many doubts that remained in the relationship since the significant changes took place during the periods. In addition, other studies on this problem largely focused on other perspectives, which introduced several variables, from the 'Bandung forum' in 1947 to the 'Indo-Soviet Treaty of Peace, Friendship and Cooperation' in 1971, and the five new factors that maintained the relationship, including politics, defense, civil nuclear energy, anti-terrorism co-operation, and space.

This essay's question is located in the research topic of foreign relations and policies in Asia. To start with, background information is needed. Firstly, the outlook of the world around 1947 is presented. In September 1946, Nehru decided to make the Indo-Soviet relationship closer, so he would want to establish a foreign relationship with Russia. Being instructed by Nehru, India's national defense minister Krishna Menon had an interview with Soviet Foreign Minister Molotov. Though the British stood against the decision, Krishna Menon met Molotov in Paris on September 28, 1946. 
On June 25, 1947, two weeks before the Mountbatten plan for the partition of India was announced, Nehru had made public the appointment of his sister as India's first ambassador to the USSR. On October 23, 1947, the Soviet Union also announced the appointment of its first ambassador to India, K.V.Novikov, which represented the formation of the foreign relationship between India and the Soviet Union.

The essay will also focus on the Indo-Soviet relationship during 1971. Background information will be provided as followed. In 1971, the country near India, Pakistan was unstable. The Pakistani military, under the commands of General Tikka Khan, used heavy weapons for almost a week to attack East Pakistan's largest city Dhaka, which resulted in a mass exodus of mostly-Hindu Bengalis, who fled to India. Besides, Yahya Khan, who led the Pakistani leadership, had a close personal friendship with American President Richard Nixon and had excellent diplomatic relations with China, whose leader is Chairman Mao. Under those circumstances, Gandhi was uncertain whether to send the troop or not. Under these circumstances, the Soviet Union stood out and helped India. When the Treaty of Friendship and Cooperation was signed, the United States and Pakistan finally reduced the action to enhance military force in Pakistan and stopped their attack. Consequently, the analysis of this case was essential due to the unpredictable ideology and political systems as well as the foreign relations during that time. In addition, this case also applied to other countries of medium size and large size.

This topic is important because it provides information to the national government and international organizations, which will help to solve the problems efficiently. Moreover, it can help change the world due to its applications in other countries with similar problems.

This essay will be divided into several sections. After the introduction, Section I would reveal the current literature. Section II will present the theoretical framework that argues credibility and external threats would affect India's foreign policies. In addition, several sub-contentions will be demonstrated in Section II. The remaining sections will implement the theory to a case to testify its reliability. Section III will give an example of "two highs", namely, high reliability and high external threats in the 1970s. Section IV illustrates a case of high external threats and low reliability from 1991 to 1993. Section V demonstrates the example of "two lows" from 1947 to 1953. Section VI tests the theory of "high reliability and low external threat" from 1993 to 2013.

\section{LITERATURE REVIEW}

The research on the relationship between Russia and India mainly focuses on historical research. It mainly divides the relationship between Russia and India from 1947 to now and summarizes the characteristics of each period. Then it analyzes the specific performance of each period. However, most of the papers are subjective interpretations, which does not rise to the height of the theoretical framework.

In the book entitled "analysis, review, and Prospect of India's foreign policy", Sumit Ganguli interpreted India's relations with other countries from the perspective of qualitative Analytic hierarchy process (AHP) [1]. The research on India's foreign policy orientation mainly depends on the following four factors: the change of international system structure, the change of international system process, the promotion of domestic interest groups, and individual leaders. Figure 1 illustrates the logic of Ganguli's theory. The conceptual difference between international system structure and international system process lies in: the former mainly refers to the distribution of system power and the formation of power pattern, which lays much emphasis on material factors. The latter mainly refers to the distribution of institutions and ideas in the international system, paying much attention to nonmaterial factors. In a word, the core of the former lies in power, while the latter lies in the system and cultural concepts.

The advantage of this method is that it is more comprehensive. On the one hand, four variables determine India's foreign policy orientation. The problem of Ganguli's theoretical framework is that there are too many variables set, and the inevitable result of too many variables is that the theory is not concise enough.

Another problem is that the lack of conciseness leads to limited explanatory power. In addition, there is a high degree of overlap between these four variables. Factors at the international system level may be the cause of domestic factors. In fact, there is no clear distinction between domestic and international causes. For example, it is mentioned in the book that from 1991 to 1993, Russia completely turned to the West in the process of the system. In order to gain the trust of the west, Russia completely imitated the western economic model and adopted shock therapy, resulting in the collapse of the domestic economy. Therefore, Russia required India to pay trade costs in hard currency, which was very unfavorable for India with foreign exchange reserves at that time. As a result, India's relations with Russia are cold. This shows the shortcomings of Ganguli's theory. The domestic and international systems are separated, we will obviously deviate from the facts and fail to pay attention to the complex 
interaction effects of the three levels. To avoid the shortcomings, I provide a revised version in figure 2 . It can be found that the process of the system has led to the domestic policy of Russia. The system is the root cause, while the domestic is the direct cause. Nevertheless, figure 2 still incomplete to explain the changes in India and Russia's relationships.

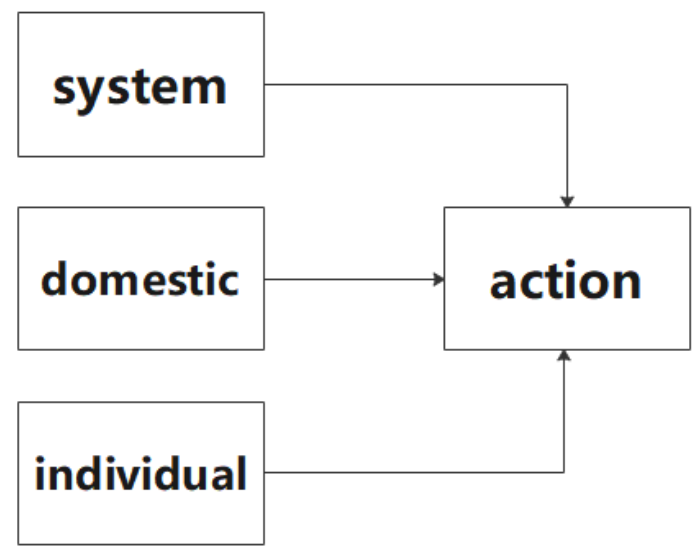

Figure 1 Ganguli's logic demonstration. Source: selfmade by the author

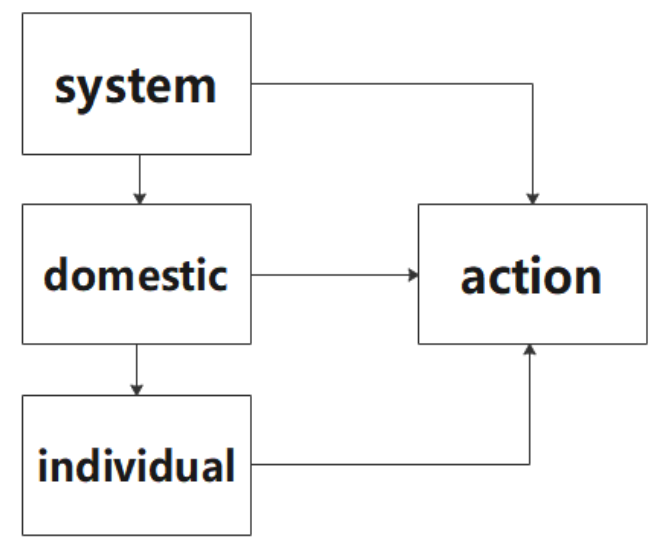

Figure 2 The revised version of Ganguli's logic demonstration: self-made by the author

\section{THEORETICAL FRAMEWORK}

India's foreign relations policy to Russia is related to two independent variables, one is external threats and the other is credibility.

This part of the paper would focus on the definition and application of external threats. First, this paper would quote other essays to illustrate some definitions. In Gehring's essay, External threat, Group-Identity, and Support for Common Policies- The Effect of the Russian Invasion in Ukraine on European Union Identity, Gehring mainly focused on the military threat posed by other countries [2].

In this paper, the definition is partly agreed upon. Since there were many potential threats remaining, this paper would discuss other potential threats such as some conflicts not readily happened.

Though Gehring's definition is not perfect, it would be helpful to analyze the strengths and weaknesses of Gehring's essay. Gehring's essay was close to reality because Gehring used the most obvious and the most important factor to analyze the problem of Russia and Ukraine, explaining why Ukraine and the EU would stand together to strengthen their identities and thus fighting against Russia. Moreover, Gehring's essay also focused on accurate data about to what extent external threat and EU identity associate. By showing the pvalue and $\mathrm{SE}$ of the figure, Gehring could convince other scholars and readers.

However, Gehring's paper also came up with some flaws. For instance, it did not present the causation of the two factors. In other words, it was difficult for the readers to understand why would external threats be positively related to EU identity. It regarded material as ontology, which is inadequate.

This paper would focus on other potential threats. For instance, India would face potential threats such as Sino-Indo relations as well as US-Indo relations. These threats were hidden, not happened yet, but would warn India to get ready for a conflict.

Reliability is another variable this essay focuses on. Douglas M. Gibler stated in The Costs of Reneging Reputation and Alliance Formation that decision-makers will consider the reputations of another country when negotiating with the country [3]. He stated that international theories confirm the value of being able to credibly signal intentions during a time of crisis, that honored commitments should build credible reputations, increasing the likelihood that other leaders expect future commitment will be honored, too. That is to say, reliability in international relations refers to how honest the state was when making commitments, and countries intend to also be honest in keeping commitments when the other country it is negotiating has been reliable in keeping commitments and will be willing to form an alliance. Gibler used the case of USA president Nixon's abandonment of Vietnam due to lack of reliability. Gibler intended to create a well-developed theory of reliability in international relations, and he has strong cases to support him. However, his argument on reliability still has flaws.

Gibler's theory of reliability seems to make the situation go to an extreme, making the process of judging alliance a simply yes-or-no judgment. The countries only have two options: to become an alliance or not, and the judgment of alliance is simply based on whether the country has been honest in the past. Gibler underestimated the complexity of game and negotiation between stated, that the honesty of a state can actually be pretended. In addition, the judgment of the reliability 
of a state is also more complicated than simply judging the past reputation of the state. Decision-makers have to consider the amount and extent of promises. To look at which promises the state had kept and the extent of those promises. In addition, the relationship of the state with rivals and the threat it can have to rivals is also important. Therefore, in this essay, it is believed that the meaning of credibility is two-fold: the credibility to allies and the extent of threats to rivals.

India's foreign relations policy to Russia is related to two independent variables, one is external threats and the other is credibility. This leads to the following four basic assumptions:

1. When the external threat is relatively high and the credibility of an ally is relatively high, India will adopt a short-term alliance. First, alliances are the most effective way to fend off strong external threats, and relatively high levels of credibility will keep India's costs to a minimum. Therefore, the alliance is the best choice.

2. When the external threat level is high but the credibility of Russia is low, India will choose the "discard" strategy and actively looks for an alternative strategy of self-help.

3. When Russia's help is credible but the external threat is relatively low, India will choose partnership rather than alliance. This is because although the alliance guarantees security, it also carries a high cost.

4. India will adopt the policy of non-alignment when the credibility of Russia's support is low and the external threat is low.

It can be vividly demonstrated in the following Table 1:

Table 1 theoretical frameworks of India-Russia political relationship

\begin{tabular}{lll}
\hline $\begin{array}{l}\text { External } \\
\text { threat }\end{array}$ & $\begin{array}{l}\text { external threat } \\
\text { credibility is } \\
\text { relatively low, only } \\
\text { one kind }\end{array}$ & $\begin{array}{l}\text { the external threat } \\
\text { is relatively high, } \\
\text { including two kinds }\end{array}$ \\
$\begin{array}{l}\text { Russia's low } \\
\text { credibility }\end{array}$ & Non-aligned & $\begin{array}{l}\text { abandonment and } \\
\text { look for } \\
\text { alternatives }\end{array}$ \\
$\begin{array}{l}\text { Russia's high } \\
\text { credibility }\end{array}$ & partnership & de facto alliance \\
\hline
\end{tabular}

\section{HIGH RELIABILITY AND HIGH EXTERNAL THREAT}

When India faces relatively high external threats and its potential ally, the Soviet Union, has relatively high credibility, India tends to seek an alliance with the
Soviet Union. The relations between the Soviet Union and India in the 1960s and 1970s can reflect India's strategic choice.

\subsection{India's external threats}

From the 1960s to the 1970s, India's surrounding security environment was very severe. The threat to India is two-fold. Firstly, India faces a direct threat from China. For example, after the Sino-Indian border war in 1962, India saw China as the biggest direct threat. Additionally, in 1967, armed conflicts broke out again between China and India at the Naidula pass, and the instability of the regional security situation made SinoIndian Relations turn from bad to worse.

In addition, India faces potential threats from the United States and Pakistan. To be more specific, since the partition of India and Pakistan, India and Pakistan, as the two largest countries in South Asia, have been fighting for the dominance of South Asia. However, Pakistan is weak, so it has to actively seek foreign aid. The United States wanted to contain the expansion of the Soviet Union in South Asia, so it actively sought to establish a military alliance with Pakistan. On May 19, 1954, the United States and Pakistan signed the US Pakistan Joint Defense Assistance Agreement and the US Pakistan bilateral defense agreement and formally concluded a military alliance. In the same year, Pakistan joined the Southeast Asia Treaty Organization. Since then, the two countries also signed the US-Pakistan bilateral military cooperation agreement on March 5, 1959, and Pakistan joined the Baghdad Treaty Organization, becoming the only country in Asia that is in the two major organizations, thus consolidating the US Pakistan military alliance. The United States has also actively provided military assistance to Pakistan, which has greatly enhanced Pakistan's strength and made India fear.

\subsection{Russia's credibility}

Around 1971, in India's view, Russia's credibility was relatively high. Russia's credibility is reflected in the following aspects. First of all, Russia's national power is strong enough to provide India with strong assistance if it chooses an alliance. From the 1960s to the 1970s, the international situation changed obviously. Because the United States was deeply involved in the Vietnam War and its domestic turbulence, as a consequence, its power declined, so it had to be on the defensive in the bipolar game between the United States and the Soviet Union. To be more specific, In 1969 Nixon made it clear that defense depended on allies rather than the US itself. This means the USA start to austere. At this time, the Soviet Union was on the offensive side. First, the Soviet Union actively expanded 
in the third world; second, the Soviet Union exerted more control over Eastern Europe.

Secondly, the credibility of the Soviet Union is also reflected in its attitude towards potential allies and enemies. Specifically, the Soviet Union held a clear hostile attitude towards India's direct threat to China. For example, in the Sino-Indian Kongka pass conflict in 1959, the Soviet Union obviously stood on the Indian side. However, fierce military conflicts broke out between China and the Soviet Union on treasure island. The Soviet Union and India share a common enemy, which provides favorable conditions for two countries to approach each other. In addition, since the 1950s, the Soviet Union has been providing economic assistance to India, and the leaders of the two countries have been exchanging visits. This also provides an opportunity for the two countries to move towards an alliance

\subsection{India's choice}

Due to the high credibility of the potential ally, the Soviet Union, and the greater external threat that India faces, after weighing the pros and cons, India decided to make a de facto alliance with the Soviet Union. In 1971, New Delhi and Moscow signed a "peace, friendship, and cooperation" agreement, in which the two sides promised to help each other under known military threats. In addition, the economic and trade cooperation between the two countries has been further deepened. For example, in 1973, the two countries signed the "Soviet Indian joint declaration" and both sides decided to settle accounts in rupees.

\section{HIGH EXTERNAL THREAT AND LOW RELIABILITY}

When India faces relatively high external threats and the Soviet Union has low credibility, India chooses to have diversified diplomatic foreign policies. The relation between the Soviet Union and India around 1991 1993 can justify the reasons.

\subsection{India's external threats}

Firstly, Pakistan and India have long been unfriendly towards India. Therefore, it was common that they had a war called Siachen Conflict, caused by a vague boundary when they negotiated their own country's territory. The United Nation held that they won't fight against each other at such a high altitude, so surprisingly, the war began. Secondly, India also suffered from the unipolar hegemony of America. Thirdly, in 1987, China also had a conflict with India, this was the third time when China had a conflict with India along the boundary, leading to tension among the two countries again. In conclusion, India faced high external threats from other countries.

\subsection{Russia's credibility}

However, at this time, after the deformation of the Soviet Union, Russia didn't have the incentive to ally with India. Russia's power has decreased since the deformation. In addition, from 1990 to 1993, Russia's arms sales towards India have decreased sharply because Russia has suffered a lot from its downturn of military power. This implied to India that the credibility of its alliance is not reliable.

From another scholar, Gidadhulbi, 1996 Russia's trade with India contributed a mere $1 \%$ of Russia's overall trade [4]. This indicated that after the treaties signed by both countries, Russia had not recovered from the repression of the economy. Russia tried to overturn its deficit budget in its own economy, which will be recovered through exports. Russia would have to trade with other countries to turn the foreign currency into its own country to save the domestic currency. India was not enough. From this instance, Russia's credibility toward India was quite low.

\subsection{India's choice}

Under such circumstances, the reaction of both countries had their reasons. According to scholar Kooper, she quoted that during 1993, the two countries had tried to negotiate to solve the questions [5]. They signed a Treaty of Friendship and Cooperation, and a year later they followed it up with a Military-Technical Cooperation agreement. This was a progressive policy from Russia's leader, Yeltsin. They tried to fix the two countries' relationship through an economic base; however, Russia's economy has kept falling. The downside of Russia's economy directly affected the trade between India and Russia, contributing to an unbalanced rupee-rouble rate. What's more, Russia has reduced its arms sales to India due to the downside of the economy, which made the relationship between the two countries looser. This situation would somehow result in a diversified foreign policy of India.

Moving to the last part of this section, this paper would also like to mention Indo-Russia relations. From scholar Nandy, the relationship had always been a complicated one but not a hostile one [6]. The highlevel meeting between the two countries in 1993 and 1994 agreed on multi-dimensional bilateral relations. Both countries agreed to fight against international terrorism. More importantly, though there was a sharp decline in arms sales of Russia, Russia had negotiated for arms agreements worth Rs. $\$ 650$, which implied that the relationship had always continued between the two countries.

This paper would also focus on the topic of how India reacted to high external threats and low credibility from alliances. India harbored the strategy of "go east", 
which aims at building a diversified diplomatic relationship. At this time, only Russia wouldn't have the strength to help India, it was time that India should find other ways to maintain its position in the world. That's the reason that India would implement the strategy of diversified foreign policy.

\section{LOW EXTERNAL THREAT AND HIGH RELIABILITY}

This section will focus on the situation when India was facing low external threat and high reliability. Evidence is founded in the period after 1993.

\subsection{India's external threat}

After 1993, India has faced relatively small external threats. On the one hand, China India relations have greatly improved. This is because China had a strong incentive to develop a domestic economy so it had to maintain a relatively stable surrounding security environment. Since India is the second-largest neighbor of China, it has to maintain a relatively harmonious relationship with India. For example, according to India Abroad in February 2005, China-India's "strategic dialogue" was formalized and the "strategic partnership for peace and prosperity" was announced in April of the same year [7]. From 2003 to 2005, China gradually hinted at and formally acknowledged Sikkim as a state of the Indian Federation, thus abandoning its policy of refusing to recognize India's merger of Sikkim for more than 30 years. In addition, China and India actively cooperate in the field of non-traditional security. In 2005, China absorbed India as an observer state of the Shanghai Cooperation Organization, and both sides also launched military exercises to enhance friendship.

Moreover, due to trade reasons, the United States and India have also been closed since 1993, so India is facing relatively small external threats.

\subsection{Russia's credibility}

After 1993, Russia's credibility has gradually recovered. On the one hand, Russia's concession to the West did not exchange for the economic assistance from the west to Russia. On the contrary, the expansion of NATO made Russia abandon its fantasy about the West. Therefore, Putin had to implement the "double-headed eagle policy" after taking power and actively develops diplomatic relations with Asian countries [8]. From the perspective of willingness, Russia has the will to resume its traditional friendly and cooperative relations with India. Russia's will can be reflected in actively promoting cooperation between China, India, and Russia and actively launching joint Russian India military performance.
Moreover, although Russia has been weakened, it still maintains a large number of advanced weapons and military technologies, for example, space technology and satellite, which always has an advantage in asymmetric competition. For instance, compared with rocket and USA, Russian satellite has simple material and low cost, but it has the characteristics of durability, and it is not lost to the space satellite and rocket in the United States in performance and function.

In addition, the personal characteristics and governing principles of Russian domestic leaders after 1993 can also add value to Russia's credibility in India. Putin has carried out dictatorship at home, fought against the dissident forces, and almost held Russia in his hands [9]. Therefore, India does not have to worry about the phenomenon of Russia's political and strategic swing. In short, in India's view, Russia is still a big country and has the power to help India. And there are many signs of Russia's willingness to cooperate. Therefore, Russia has enjoyed high credibility since 1993.

\subsection{India's choice}

In 2002, India and Russia signed the Delhi Declaration, which made it clear that the two countries should build a comprehensive strategic partnership. India chooses to establish a partnership based on costbenefit calculations [10]. Although the alliance can effectively resist external threats, it will also cause a great burden on India. Therefore, the best choice is to seek a partnership but not to align.

\section{CONCLUSION}

In conclusion, the paper has first discussed the hypothesis: credibility and external threats would affect India's foreign policies and brought out four subcontentions. Firstly, when the external threat is significant, and the reliability of assistance from Russia is high, India will choose to adopt a short-term alliance. Secondly, when the external threat is significant and the reliability of assistance from Russia is low, India will choose to abandon assistance from Russia and seek substitutes. Thirdly, when the external threat is not significant but the reliability of assistance from Russia is high, India will adopt a relationship based on nonalignment. Then the essay has used the case study of the Indo-soviet relationship in 1971 to testify the theory.

The research not only deepens people's understanding of the status quo of the Russia-India relationship but also develops a theory that can help predict and understand the future tendency of the Russia-India relationship, based on the two variables of reliability and threat. With the implementation of the theory discussed in the essay, NGOs and governments 
of different countries can treat their relationship with India and Russia more sensibly.

Yet, the research still has limitations that the analysis in the essay might incomplete or one-sided. To be more specific, the paper only discussed reliability and threat as two variables that affect India-Russia relations. However, the situation, in reality, is more complicated and the structure of the current IndiaRussia relation might include more variables that are not discussed in the essay. In addition, the single case of India-Russia relation provides limited explanatory power which may not be capable of fully explaining other cases.

Therefore, future studies can be directed towards analyzing other cases of India-Russia relation or other similar cases of the relations between large states. In addition, to fully understand the phenomenon, it is worthwhile to explore other reasons that shaped the India-Russia relationship.

\section{REFERENCES}

[1] Ganguli , S (2015) 'Analysis, Review and Prospect of India's Foreign Policy', World Knowledge Publishing House.

[2] Gehring, K (2020) 'External threat, group identity, and support for common policies-The effect of the Russian invasion in Ukraine on European Union identity'CESifo Working Paper Series

[3] Gibler, D. M (2008) 'The costs of reneging: Reputation and alliance formation', Journal of Conflict Resolution, 52(3): 426-454.

[4] Gidadhubli, R. G (1998) 'Moving towards consolidation: India-Russia trade relations',. Economic and Political Weekly, 33(3): 91-92.

[5] Kapoor, N (2019) 'India-Russia ties in a changing world order: In pursuit of a special strategic partnership', ORF Occasional Paper No.12

[6] Nandy, D. (2020) 'India and Russia: An Investigation of Relational Equations (1991-2020)', Journal of Social Science Research, 2(2): 116-132.

[7] India Abroad,14 May 2004, 'China Map Puts Sikkim in India' p. 12.

[8] Qureshi, K. (1963) 'The Soviet Union, Pakistan and India' Pakistan Horizon, 16(4): 344-355.

[9] Watson H (1962) 'The Communist Powers and Afro-Asian Nationalism', Unity and Contradiction, New York: Praeger

[10] India Abroad,14 May 2004, "China Map Puts Sikkim in India" p. 12. 